\title{
THOMAS HOBBES AND THE INVENTED TRADITION OF POSITIVISM: REFLECTIONS ON LANGUAGE, POWER, AND ESSENTIALISM
}

\section{JAMES BOYLE† \\ INTRODUCTION}

This is an essay about the legal theory of Thomas Hobbes and about the things that are revealed when one compares Hobbes's ideas with the main line of legal positivism. Hobbes occupies a paradoxical position in traditional jurisprudence-revered but frequently overlooked, hailed as a precursor but not as a founder, and used alternately as a bogeyman and an illustration of the difference between political and legal theory. If one actually looks at Hobbes's works, rather than footnoting them, cite unseen, one finds a rich stewpot of ideas; great dollops of wisdom about language, interpretation, power, legitimacy, epistemology, definition, scholasticism, human nature, and law. Of course, Hobbes has never been ignored. He still plays Mutt to Locke's Jeff in college courses in political theory. But at a time when legal theorists are rediscovering the fact that there is no bright line separating legal from political theory, that questions of legitimacy may resolve themselves into questions of epistemology, and that language and power are inextricably connected, Hobbes's work deserves rereading, if only to see how legal positivism defines its own margins.

The title of this essay is taken from a book ${ }^{1}$ that describes some of the most remarkable examples of the manufacturing of tradition-the creation of myths that are then projected back into history. I want to suggest that something of the sort has happened with positivist legal philosophy. Of course, it would be ridiculous to suggest that positivism is as much an invented tradition as, for example, the Indian ceremonies that actually came from the British preconceptions about what a "native ceremony" should look like. ${ }^{2}$ We can all go back to the great texts and find what seem to be undeveloped and unsophisticated precursors

- Copyright 1986 by James Boyle. All rights reserved.

†Associate Professor, Washington College of Law, American University. LL.B. 1980, Glasgow University; LL.M. 1981, Harvard University. Special thanks go to Michael Madow, Gary Francione, Peter Jaszi, and Ed Baker.

1 The Invention of Tradition (E. Hobsbawm \& T. Ranger eds. 1983). 182-83.

2 See Cohn, Representing Authority in Victorian India, in id. at 165, 165-78, 
of the positivist position. But that is intellectual history as seen through our end of the telescope. If the history had been a little different, we might be going back to demonstrate that all of the great theorists were fumbling their way toward a truth-community theory of law. ${ }^{3}$ The precursors for that are there too; they are part of the material that we literally (and literarily) marginalize in our construction of the positivist lineage. ${ }^{*}$

In an earlier article,, 5 claimed that all definitional debates were fuelled by a common fixation and that they, in turn, fuelled a repeating pattern of arguments and evasions. Once identified, this pattern can be used either to manipulate or to unravel the definitional question, whether one is defining science, law, or false imprisonment. ${ }^{6}$ In this Article, I will further develop these ideas within the context of positivist legal philosophy. My thesis is that legal positivism best can be understood as an example of this kind of argumentative pattern. The invented history of positivism turns out to be the process by which theorists sacrificed most of the meaning in their canonical texts to the maintenance of the definitional project. The idea is probably too complicated to be developed properly in an introduction, but a skeletal version runs something like this:

(1) One can go a long way (fudge, fudge) with the pragmatist idea that definitional action should be guided by a purpose. ${ }^{2}$ That is to say,

\footnotetext{
3 That is, the theory that the truth of a proposition-whether about the definition of law or the correct decision in some particular case-depends on its acceptance within the relevant professional community. The general trend toward truth-community theory is usually illustrated (perhaps unfairly) by T. KUHN, THE STRUCTURE OF SCIENTIFic Revolutions (2d ed. 1970). See also Boyle, The Politics of Reason, 133 U. PA L. REv. 685, 730 n.141 (1985) for an inelegant footnote summary.

- I have not tried terribly hard, but presumably one could see Holmes and Coke as stressing the importance of a truth community. See Prohibitions del Roy, 12 Co. Rep. 64, 65, 77 Eng. Rep. 1342, 1343 (K.B. 1608) ("artificial Reason [attained by] long study and experience"); O.W. Holmes, The Path of the Law, in Collected LEGAL PAPERS 167, 173 (1920) ("prophecies of what the court will do in fact . . . are what I mean by the law"). Seen in this light, the legal community becomes the final arbiter of both methodology and of the ultimate truth of propositions. Of course, such a reading may seem fairly silly, but it is much more sensible than some of the positivist readings that $\mathrm{I}$ am going to discuss.

s Boyle, Ideals and Things, 26 HARv. INT'L L.J. 327 (1985); see also J. Boyle, Critical Jurisprudence (rev. ed. Feb. 1986) (unpublished manuscript on file with the University of Pennsylvania Law Review) [hereinafter Critical Jurisprudence] (general investigation of the recurring patterns of circular argument produced by attempts to find true meaning of legal terms).

- See Critical Jurisprudence, supra note 5, at 2.

7 A definition of law is useful or useless. It is not true or false, any more than a New Year's resolution or an insurance policy. A definition is in fact a type of insurance against certain risks of confusion. It cannot, any more than can a commercial insurance policy, eliminate all risks.
} 
one can either dissolve or resolve a definitional question by asking, "Why do you want to know?"

(2) The great positivists were, implicitly or explicitly, engaged in definitional actions that were deeply infused with purpose. For example, Hobbes was shoring up the power of a centralized state by appearing to deduce, from the very definition of law, the need to subordinate all forms of normative authority to the power of the sovereign.

(3) Although they may have said that they were defining law in the abstract, the great positivists' work makes more sense (to me) if read in the light of those purposes.

(4) But in order to make legal positivism a venerable tradition we have to ignore those different purposes, gather a set of texts together, and claim that there is a common theme weaving its way down the centuries toward us. This has the bizarre effect of making Austin and Hobbes seem "essentially similar," but even more strangely, it makes H.L.A. Hart a more sophisticated thinker than Hobbes. ${ }^{8}$

So what is positivism? Like any invented tradition, positivism is most easily described by reference to what it is not. Positivists are the ones who have denied, minimized, or pooh-poohed the role of morality or religion in the "concept of law" and who have correspondingly stressed the role of the state and its authorized organs. ${ }^{9}$ Austin provides perhaps the classic positivist argument: "The existence of a law is one thing; its merit or demerit another. Whether it be or be not is one enquiry; whether it be or be not conformable to an assumed standard, is a different enquiry." 10 By repeating this slogan often enough, and by relying on one of the many contradictory, implicit definitions of law shared by those who have had legal training, ${ }^{11}$ the positivists have ef-

Cohen, Transcendental Nonsense and the Functional Approach, 35 Colum. L. REv. 809, 835-36 (1935).

Naming appears as a queer connexion of a word with an object.-And you really get such a queer connexion when the philosopher tries to bring out the relation between name and thing by staring at an object in front of him and repeating a name or even the word "this" innumerable times. For philosophical problems arise when language goes on holiday.

L. Wittgenstein, Philosophical Investigations 19 (1958). For further explanation, see infra note 11.

B And the standing-on-the-shoulders-of-giants line does not work, unless you can stand on their shoulders and do things they would think are silly.

- See, e.g., J. Austin, The Province of JuRisprudence Determined (H.L.A. Hart ed. 1954); H.L.A. Hart, The Concept of LAw (1961); H. Kelsen, Pure Theory of LaW (1967) (1978 reprint).

$10 \mathrm{~J}$. AustiN, supra note 9 , at 184 .

11 By this I mean only that a lawyer is likely to have different implicit "definitions" of law depending on whether she is advising a client, explaining law to a civics class, or arguing a case. The first probably would depend more on predictions of official behavior, the second might be a positivist account of the hierarchy of power-confer- 
fectively swept the field of their natural law foes. The positivist movement is now going through a relatively typical version of academic success-lacking the spice of a fight that was always more imaginary than real, its protagonists (almost everyone who works in traditional jurisprudence) have fallen to quarrelling amongst themselves about the proper placement of "posts" and "neos,"12 to writing articles that do little more than change a word or two in the dominant definitions, ${ }^{13}$ and, of course, to rebuilding natural law in effigy, so that they can alternately burn it (in its old form) and praise it (in its new, Dworkinian, form). ${ }^{14}$ What are all of these verbal alarums, excursions, and ambuscades about?

I do not see positivism as a grand strain of thought spanning the centuries, now being perfected by a disciplined and clear sighted cadre of theorists. Rather, I believe that the drive to "find" positivism and natural law as a continuing tension running through the ages has led jurisprudes to an impoverished conception of each side of the tension. ${ }^{15}$

ring and power-applying norms in a Western legal system, and the last might be a relatively rich description of the sources, modes of argument and analogies acceptable at a particular historical moment within the legal profession. Many jurisprudential debates consist of arguments about which is really the "correct" definition of law. Because those same debates lack any explicit discussion of why a particular purpose should be considered as forever the most fundamental, they are doomed to an erudite circularity. This is exactly the mistake that Wittgenstein is describing in the quote cited earlier. See supra note 7; see also W.H. Auden, Law like Love, in Collected Poems 208 (E. Mendelson ed. 1976).

12 See, e.g., Summers, The New Analytical Jurists, 41 N.Y.U. L. REv. 861, 86263 (1969) (distinguishing "old" analytical jurists such as Austin, Gray, Hohfeld, and Kocourek from "new" jurists such as Hart, Williams, Hughes, Dworkin, Fried, Morris, and Wasserstrom).

13 Unfortunately, I do not have the space here to deal with the complicated confession and avoidance mechanisms used by contemporary jurisprudes to deal with the charge that they are engaged in a purely definitionalist enterprise. Those mechanisms are to be subject of another article. See Boyle, Critical Jurisprudence, supra note 5. For my present purposes, it is enough to note that jurisprudes claim that they are engaged in no mere semantic dispute, but instead are identifying the prerequisites for law, or the minimum criteria necessary to call something "law," or that they are clarifying the concept of law by bringing out its most fundamental components. It is my claim-and I recognize that at this point it is no more than a claim-that the "prerequisites," "criteria," and "fundamental components" are all, in fact, resurrections of the essentialist project under another name. I offer the text accompanying notes $51-72$ infra as a partial defense of the idea that positivism has gone wrong and offer H.L.A. HART, The ConCEPT of LAw, supra note 9 and J. RAZ, The ConCEPT OF A LEgal SySTeM (1970) as paradigmatic examples of the resurrected, chastened definitionalism.

14 See, e.g., R. DwORkIN, TAkING RIGHTS SERIOUSLy (1977) (an argument for "principled" decisionmaking based on the "political rights" that, somewhat mysteriously, underpin the legal system). But see R. DwORKIN, LAw's EMPIRE (1986) [hereinafter LAW'S EMPIRE] (naturalistic political rights fade out, interpretive integrity fades in).

15 I trust that the picture of analytic jurisprudence as being fixated on the tension between positivism and natural law is so obvious as to be boringly unobjectionable. 
Both the positivist and the natural law strands need to be made supremely vague if they are to be "discovered" in every era, and in every academic debate. Thus, the paradigmatic examples of each philosophy get cut off from the political, epistemological, and rhetorical purposes which they served. (Hobbes and H.L.A. Hart are really doing "the same thing"?) In fact, one of the ironic twists of an essentialist discipline is that any attempt to provide a definition that does serve some concrete purpose will probably be seen as inferior, subjective, and partial (meaning both limited and biased). The only thing, therefore, that could save the activity from circularity and dogmatism is seen instead as a corruption. "Well, he had a reason for defining law that way."

In other words, the invented tradition of positivism does to legal theory what an individual positivist theory does to law. The individual theory reifies a definition of law by focusing on some supposedly essential quality (commands backed by threats, for example) ${ }^{\mathbf{1 6}}$ and gives this particular definition a false universality by ignoring the question of what purpose it is to serve (counselling clients, questioning the legitimacy of the state, etc.). The tradition of positivism reifies the task of defining law, making it the central endeavor of legal theory. Thus positivism gives the task of definition a false universality by separating it from the very notion of purpose. As for Hobbes, I may be right or wrong about the way that his work is presented in contemporary classes in legal theory. But if one reads Hobbes's work one cannot help but wonder how the later positivists managed to ignore both his political theory and his critique of essences, as they constructed a conceptual jurisprudence that would have been the envy of the "deceived, or deceiving Schoolemen"17 whom Hobbes loved to bait.

A note on methodology. I had two fairly unattractive choices. First, I could rely on the general knowledge of my readers to supply the conventional legal and political insights into Hobbes's work, merely inserting the occasional comment when I thought we should collapse the boundary between the political theory and the jurisprudential interpretation, or when we should reread Hobbes in the light of recent disputes about legal interpretation. Alternatively, I could go into more detail, thus running the risk that I would often be repeating well-known

\footnotetext{
Because this is a kind of unspoken structure to the discipline it is best seen in the presentation of jurisprudence for "external" consumption. See, e.g., Hughes, The Concept of Law, 3 Dictionary of THE History of IdEAS : STUdies OF SELECTED Pivotal Ideas 1-6 (1973) (distinction emerges in 5th century B.C. and continues to be source of debate).

10 See J. Austin, supra note 9, at 13-15. LEVIATHAN].

17 T. Hobbes, Leviathan 99 (C.B. MacPherson ed. 1968) [hereinafter
} 
truths. I have chosen the second risk for three reasons: (1) I hope to make the piece more accessible (even if less impressive); (2) A close reading shows that Hobbes's legal theory compares favorably with those of the subsequent positivist theorists; and (3) I think that one of the most interesting things about Hobbes is the way that he uses his definitional argument for political ends. Few people have wielded the fallacy of reification to greater effect. To understand what he does, one must go line by line through the familiar text of Hobbes's definition of law in the Leviathan. Taking this section in Leviathan as my text, I want not only to sketch the connections that Hobbes saw between definition, interpretation, and the theory of law and state, but also to show the dangerous power of the definitional argument in the hands of a master. I also want to demonstrate how an analysis of Hobbes's work leads to an understanding of the defects of the positivist enterprise.

All but one of the quotes that follow come from the pen of the most charming freeloader to have left us a memoir: John Aubrey, good friend of Thomas Hobbes and lover of wine, learning, poetry, and gossip. This is not an intellectual biography of Hobbes, and I will be making only occasional further use of Aubrey's Brief Lives. But as you read what follows, think occasionally of the Thomas Hobbes whose schoolmates called him "Crowe," whose eyes shone when he was "in discourse," who threatened from his sickbed to detect the "cheates" of the churchmen, who played tennis when he was seventy-five, who wrote love poetry when he was ninety, and who provided us with the comment that out-Wittgensteins Wittgenstein: "[W]ords are wise mens counters, they do but reckon by them: but they are the mony of fooles." 18

18 Leviathan, supra note 17 , at 106. 
Thomas HobBes

The old vicar Hobs [Hobbes's father] was a good Fellow and had been at cards all Saturday night, and at church in his sleep he cries out Trafells [clubs] is troumps. ${ }^{19}$

[I]n matter of Government, when nothing else is turn'd up, Clubs are Trumps. ${ }^{20}$

Thomas, the Father, had an elder Brother whose name was Francis, a wealthy man, and has been Alderman of the Borough; by Profession a Glover, which is a great Trade here, and in times past much greater. (Shall I expresse or conceale this glover? The philosopher would acknowledge it.) ${ }^{21}$

The day of his Birth was April the fifth, Anno Domini 1588, on a Fryday morning, which that yeare was Good Fryday. His mother fell in labour with him upon the fright of the Invasion of the Spaniards. ${ }^{22}$

When he was a Boy he was playsome enough, but withall he had even then a contemplative Melancholinesse; he would gett him into a corner, and learn his Lesson by heart presently [at once]. His haire was black, and his schoolfellows were wont to call him Crowe. ${ }^{23}$

He had a good eie, and that of a hazell colour, which was full of Life and Spirit, even to the last. When he was earnest in discourse, there shone (as it were) a bright live-coale within it. ${ }^{24}$

When Mr. T. Hobbes was sick in France, the Divines came to him and tormented him (both Roman Catholic, Church of England, and Geneva). Sayd he to them, Let me alone, or els I will detect all your Cheates

10 J. AUBREY, AUBrey's Brief Lives 148 (O.L. Dick ed. 1958).

20 T. Hobbes, Of Punishments, in A Dialogue Between a Philosopher \& A Student of the Common Laws of England 140, 140 (J. Cropsey ed. 1971)

$21 \mathrm{~J}$. AUBREX, supra note 19 , at 148.

29 Id. at 147.

23 Id. at $148-49$.

24 Id. at 154. 
from Aaron to yourselves. ${ }^{25}$

Besides his dayly Walking, he did twice or thrice a yeare play at Tennis (at about 75 he did it) then went to bed there and was well rubbed. ${ }^{26}$

I have heard him inveigh much against the Crueltie of Moyses for putting so many thousands to the Sword for Bowing to the Golden Calf. ${ }^{27}$

He fell sick about the middle of October 1679 .... He seemed ... to dye rather for want of the Fuell of Life (which was spent in him) and meer weaknesse and decay, then by the power of his disease .....28

\section{The Case for Hobbes's Status as a Positivist}

In the next two sections I make several claims. I claim that Hobbes is doing something more interesting (even if sometimes more disagreeable) than the positivist theorists who come after him and that if we analyze his work it will help us to understand the defects of the positivist enterprise. I also claim that Hobbes has been misunderstood, undervalued, and even trivialized because his picture of law shows legal interpretation, politics, and epistemology to be inseparable and this represents a challenge to the invented tradition of positivism. Before I reach these claims, I must show that Hobbes looks like a positivist; I have to demonstrate that he is arguably within the genre before I can argue that he transcends it. Is Hobbes ignored by positivists because he is not in fact a positivist? We must be more specific.

Why does H.L.A. Hart say, "[Austin's] work . . . established the study of jurisprudence in England,"29 and why does Hart devote a substantial part of his Concept of Law to arguing with Austin and not Hobbes ? $^{30}$ Why does the standard jurisprudence course feature Dworkin, Raz, Hart, Kelsen, and Austin as major players, relegating Hobbes to the introductory parade of venerable, but marginal, jurisprudes ${ }^{32}$

25 Id. at 156 .

${ }^{28} I d$. at 155.

27 Id. at 157.

28 Id. at 158-59.

${ }^{29}$ Hart, Editor's Introduction to J. Austin, The Province of Jurisprudence DeTERMINED at xvi (1954).

so See H.L.A. HART, supra note 9, at 18-70.

s1 See, e.g., J. Feinberg \& H. Gross, Philosophy of Law (2d ed. 1980) (jurisprudence textbook, Hobbes not even discussed); LORD Lloyd of HaMPSTEAd \& 
Hobbes is obviously better known than Austin as a political theorist, and he is obviously not ignored within positivist legal theory. But why is he so often relegated to the position of one of the many ancestors of the tradition, those who swept the stage for Austin to perform on? Is his method of inquiry somehow outside the tradition of the "What is Law" theorists? Is it that he is not engaged in a proper positivist search for the essence of law, or that he does not define law in positivist terms? Let us see.

In the first paragraph of his chapter "Of Civill Lawes" in the Leviathan, Hobbes tells us that "Civill Law" is sometimes used to refer to the received Roman law: "But that is not what I intend to speak of here; my designe being not to shew what is Law here, and there; but what is Law; as Plato, Aristotle, Cicero, and divers others have done, without taking upon them the profession of the study of the Law."32 Surely, one could not ask for a statement that is more in the mainstream of the definitional approach. Is it that Hobbes's definition itself is somehow lacking in terms of its positivist credentials?

And first it is manifest, that Law in generall, is not Counsell, but Command; nor a Command of any man to any man; but only of him, whose Command is addressed to one formerly obliged to obey him. And as for Civill Law, it addeth only the name of the person Commanding, which is Persona Civitatis, the Person of the Commonwealth.

Which considered, I define Givill Law in this manner. Grvill LAw, Is to every Subject, those Rules, which the Common-wealth hath Commanded him, by Word, Writing, or other sufficient Sign of the Will, to make use of, for the Distinction of Right, and Wrong; that is to say, of what is contrary, and what is not contrary to the Rule. ${ }^{33}$

This obviously fits beautifully into the positivist tradition. Hobbes is engaged in an abstract attempt to define law, and he does so in terms of the command of the sovereign. He even has a little something about prior obligation to obey, which, as we know from the rest of Hobbes's book, is based on a theory of self-interest in a hypothetical and supremely "rational" covenant to subject oneself to a supreme sovereign. ${ }^{34}$ At the very end of this definitional passage it might have looked as

M. Freeman, Lloyd's Introduction to JuRisprudence (5th ed. 1985) (Hobbes mentioned once in chapter on classical English positivism).

${ }^{32}$ LeVIaTHAN, supra note 17 , at 311-312.

ss Id. at 312 .

st See id. at 223-28. 
though Hobbes was straying into natural law ("for the Distinction of Right and Wrong"). But the final clause makes it clear that right and wrong are actually functions of the law.

So far Hobbes appears to be firmly within the positivist tradition. The standard positivist/natural law oppositions are positive law versus morality, state versus church, profane versus transcendental, command versus counsel, threats versus internalized obligation, and Will versus Reason. Positivists generally stress the left-hand side of each opposition. (Although any given positivist theorist appears to be allowed one term from the right-hand side of the table, to distinguish that theorist's theory from all the others, if nothing else.) Hobbes has already defined law in terms of the command of the sovereign, he defines commands as self-interested acts of will, ${ }^{35}$ and in one lovely passage he flips the traditional natural law idea of "law as reason" onto its head. Please read the passage that follows not only as an attack on the natural law conception, but also as an interpretive theory of law.

That Law can never be against Reason, our Lawyers are agreed; and that not the Letter, (that is, every construction of it,) but that which is according to the Intention of the Legislator, is the Law. And it is true: but the doubt is, of whose Reason it is, that shall be received for Law. It is not meant of any private Reason; for then there would be as much contradiction in the Lawes, as there is in the Schooles; nor yet, (as Sr. Ed. Coke makes it,) an Artificiall perfection of Reason, gotten by long study, observation, and experience, (as his was.) For it is possible long study may encrease, and confirm erroneous Sentences: and where men build on false grounds, the more they build, the greater is the ruine: and of those that study, and observe with equall time, and diligence, the reasons and resolutions are, and must remain discordant: and therefore it is not that Juris prudentia, or wisedome of subordinate Judges; but the Reason of this our Artificiall Man the Common-wealth, and his Command, that maketh Law. ... The subordinate Judge, ought to have regard to the reason, which moved his Soveraign to make such Law, that his Sentence may be according thereunto; which then is his Soveraigns Sentence; otherwise it is his own, and an unjust one. ${ }^{36}$

ss LeVIATHAN, supra note 17 , at 303.

s6 Id. at 316-17. 
I use this quotation to demonstrate Hobbes's partyline correctness, within the invented tradition, on the matter of the law as reason. "Whose reason?," asks Hobbes, the skeptical positivist. But the quotation gives us another reason to recognize Hobbes as a foundational positivist-he offers a theory of interpretation, which taken together with his comments about psychology, the nature of words, and the legitimation of the state, provides an edifice that is more sophisticated than is provided by Austin. (Or by Hart, Kelsen, or early Dworkin as far as I am concerned, but I realize that this is heresy.) I am going to argue that Hobbes's interpretive theory rejects the "rule of law" answer to the antinomy of freedom and order, and that this is one of the reasons why Hobbes is not given Austin's place as the foundational positivist.

\section{Hobbes's Theory of Interpretation Makes Him Unattractive to Positivists}

We must return to the quotation from Leviathan given on the previous page. One is tempted to be historicist and say that Hobbes is 300 years ahead of the game. In this short paragraph, he deals with and disposes of most of the schools of legal theory that will come after him. $\mathrm{He}$ finds objectivity to be impossible and instead plumps for a kind of privileged secular subjectivity-the Sovereign as authoritative Subject. $\mathrm{He}$ does this, not because the sovereign can claim a superior insight into the moral universe, not because the purposes and ideas of the legislator will always actually be clear or decipherable to the "subordinate Judge," but because the interpretation of the law must be final and authoritative. Let me support these rather intemperate assertions.

In coming to his conclusion, Hobbes does a lightning run through the theories that will be applied to the problem in the next 300 years. $\mathrm{He}$ rejects the idea of self-revealing texts. "All Laws, written, and unwritten, have need of Interpretation . . . [because of] the divers significations of . . . words."37 He rejects the idea that a professional speech community $^{38}$ can acquire any meaningful degree of authoritative consistency: recourse to "any private Reason" would lead to "as much contradiction in the Lawes, as there is in the Schooles." claim to an "Artificiall perfection of Reason" $"$ gets similarly short

s7 Id. at 322.

ss For the background to the idea of acquiring determinacy through speech-communities, see S. Fish, Is There A Text IN ThIS Class? (1980); T. KuHN, supra note 3; Paradigms and Revolutions (G. Gutting ed. 1980); Critical Jurisprudence, supra note 5 , at 2 .

so LeVIATHAN, supra note 17 , at 316.

10 Id. at 317. The actual quote, from Sir Edward Coke, concerns the "artificial 
shrift. The "reason" that drives the law is going to have to be that of "the Artificial Man the Common-wealth." "41 Of course, Hobbes wants deference to the sovereign, but he does not seem to imagine that the sovereign's will can always be discovered, or even that it always exists. That is not the point.

To [the Sovereign] therefore there can not be any knot in the Law, insoluble; either by finding out the ends, to undoe it by; or else by making what ends he will, (as Alexander did with his sword in the Gordian knot,) by the Legislative power; which no other Interpreter can doe. ${ }^{42}$

Legal interpretation will not, and cannot, be "object-ive"; it must come from some unanswerably authoritative Subject.

Most political and legal philosophers have tried to edge away from this conclusion. Our philosophical tradition has attempted to reconcile the antinomy of freedom and order by postulating "a rule of laws and not men." We can have authority without personal domination if we have democracy and if legal interpretation is "objective"; the law comes from within the fetishized textual objects rather than from anyone's willful decision. But Hobbes, like Marx and Feuerbach, is critical of the pretense that a desired quality is somehow inherently present in an external object. ${ }^{43}$ For Hobbes, law is about power, so when you give him the happy naturalistic conceit that it can never be against reason, he turns the whole meaning of the phrase on its head by agreeing, and then saying, "Whose Reason?"44

Reason" of the law, which "is an Act which requires long Study and Experience, before that a Man can attain to the Cognizance of it." Prohibitions del Roy, 12 Co. Rep. 64, 65, 77 Eng. Rep. 1342, 1343 (K.B. 1608). I cannot but add Aubrey's comment on Coke: "He will play with his Case as a Cat would with a mouse and be so fulsomely Pedantique that a Schoole boy would nauseate it. But when he comes to matter of Lawe, all acknowledge him to be admirable." J. AUBREY, supra note 19, at 68. Despite his present status as the lawyer's hero, Coke does not seem to have been the most lovable of men. After his death his wife had this to say. "We shall never see his like again, praises be to God." B.M. Harl. Ms. 7193, fol. 16, quoted in S. THORNE, Sir EDWARD Coke, 1552-1952, at 4 (1957) (Selden Society Lecture of March 17, 1952). It is interesting to note that the authoritarian Hobbes seems to have been quite delightful.

41 Leviathan, supra note 17 , at 317.

42 Id. at 322.

43 See, e.g., L. Feuerbach, The Essence of Ghristianity (M. Evans trans. 2d ed. 1854); Marx, Estranged Labour, in The MARX-Engels Reader 56 (R. Tucker ed. 1972). Feuerbach believed that "God" was a metaphor for human potential. Marx believed that production under capitalism is objectified so that the object seems to rule the worker and not vice-versa. In both cases a choice-one religious, one economic, political, and systemic-is denied. I think that Hobbes saw a total faith in rules as involving the same pattern of projection, denial, and false necessity.

4 Leviathan, supra note 17 , at 316. 
Is it because of this refusal to accept an answer that would fit within the mainstream of legal and social theory that Hobbes was passed over as the real parent of positivism? Is this the reason the role went to Austin? There has certainly been criticism of Hobbes's theory of interpretation. For example, in the context of a discussion of Sir Matthew Hale's response to Hobbes's ideas, Professor Gray claims Hobbes makes two errors: "[ $t$ ]he fallacy of excessive realism"4s and " $[t]$ he compensating fallacy of excessive faith in natural law adjudication." $" 48$ According to Gray, Hobbes

was aware that judges do not and cannot settle cases merely by applying rules given them by the legislature or by tradition, without reference to the reasonableness of the result. $\mathrm{He}$ concluded that the reasonableness of the result according to the judges' lights is the only thing that judges can or do really inquire into. ${ }^{47}$

But despite the criticism, and despite the fact that it would fit a great many of my own theoretical prejudices to do so, I do not feel I can argue that this is the main reason the positivists have rejected Hobbes. The authoritarian antiliberalism of Hobbes's interpretive jurisprudence has probably played a part in making him a sort of disreputable ancestor, but $I$ think that there is an even stronger set of reasons for his venerable, but marginal, status. By going through these reasons I hope to develop my critique of the invented tradition of positivism and at the same time to deepen our understanding of Hobbes as a legal philosopher.

I should note here that the arguments that follow are not dependent on the idea that Hobbes's theories have been distorted and underrated by the positivist tradition. I believe they have been, but the same information can provide an answer to the question, "What is interesting about Hobbes's argumentative method and his legal theory?" as well as to the question "Why has Hobbes been marginalized?"

(s Gray, Editor's Introduction to SIR MATTHEw HAle, The History OF THE CoMmon LAw of ENGLAND, at xxxii-xxxiii (1971).

46 Id. at xxxiii.

47 Id. at xxxii-xxxiii. Sheldon Wolin makes a more general observation that might bear on the realist "feel" of Hobbes's work. "Thus Machiavelli, Luther, and Calvin might pray to different gods, and Hobbes pray to none at all, yet all four were at one in their response to chaos: chaos was the material of creativity, not a cause for resignation." S. Wolin, Politics and VISION 243 (1960) (emphasis added). This may provide yet another reason to think that Hobbes has a message for post-realist lawyers. It would be hard to find a more compressed statement of the peculiar existential and epistemological transformation brought about by first-year law school. 


\section{The Theoretical Richness of Hobbes's Work is aN Implicit Challenge to The Sterility and Circularity of Positivist Definitions}

I argued above that the invented tradition of positivism does to jurisprudence what individual positivist theories do to law. The individual positivist theory puts forward an objectified definition of law, detaches it from any particular purpose, and thus conveys upon it a false universality. The tradition of positivism does the same thing on the meta-level; it objectifies the task of definition itself, detaching it from the very notion of purpose. Consequently, many jurisprudence scholars do not believe that they are defining law to serve some hidden agenda. They honestly believe they can define law in the abstract, and thus their work is convincing because of the very absence of purpose-read "lack of bias" - that makes it so empty. Hobbes, on the other hand, has a very explicit purpose: to tie the concept of law into a science of politics. ${ }^{48}$ Unlike Hart, Hobbes does not imagine that it is possible to understand someone's obligation to obey the state by analyzing, in the abstract, the conceptual structure of law. ${ }^{49}$ Instead of making pretty verbal distinctions between "being obliged" and "having an obligation," Hobbes starts from a set of "compositive-resolutive" conceptions of human nature, power, and the state, which, when put together, sound suspiciously similar to (if more interesting than) modern public choice theory. From these, he builds his idea of the nature of law. What do modern jurisprudes think of his project?

The imperative conception of law emerged in modern times concurrently with the development of the modern state. The English philosopher, Thomas Hobbes, an original thinker but not a lawyer nor even primarily interested in legal philosophy, came close to the imperative conception when he said: "Law properly is the word of him that by right hath command over others."

The context of this passage shows that Hobbes included political authority and political sanction (implied in "command") in his conception. "By right," however, introduces a qualification, that the sovereign's right to command rests

48 See Leviathan, supra note 17, at 311-12.

19 See H.L.A. HART, supra note 9, at 77-96. Hart states, for example, that "most of the features of law which have proved most perplexing . . . can best be rendered clear, if these two types of rules [primary and secondary rules] and the interplay between them are understood." Id. at 79.

so See id. at 80 . 
upon the social contract which is presupposed in the establishment of a sovereign. The imperative conception of law could not emerge until the question of the political justification of the state, or of sovereign power, was distinguished from the question, by what criteria does one determine, in a modern state, that a particular thing is or is not a part of the law of that state? ${ }^{\text {s1 }}$

In other words, Hobbes's jurisprudence is still cluttered up with an attempt to explore the political justification of the state. The "true" positivist, imperative theory cannot come into existence until the definition has been purged of any such task. You may be tempted to respond that, even if it is not as theoretically exciting as Hobbes's project, it is nevertheless valuable and worthwhile to work out some method of identifying what is or is not law in a particular state. I quite agree, but if that is Patterson's justification for the imperative (i.e., the positivist command) theory of law, then he seems to be wide of the mark.

Let us assume that Patterson wants a noncircular definition for the "law of the state" (although that is by no means clear). The content of such a definition will obviously change depending on his purpose in asking for it. For advising a client, he might want a definition focusing on the prediction of judges', or other officials', behavior. ${ }^{52}$ For constructing a legal argument, he might want a list of the documents and patterns of behavior that were considered by the legal profession of that time and place to be "authoritative sources" and an explanation of the modes of argument and the analogies and metaphors that were thought to be persuasive in that particular period..$^{6 s}$ As a judge, he might want a little of the latter, combined with a normative theory of the good, or a formal, $^{54}$ or realist, ${ }^{85}$ or Dworkinian, ${ }^{56}$ or Posnerian ${ }^{87}$ theory about ob-

31 E. Patterson, Jurisprudence: MEN and IdeAs of the LAW 83-84 (1953) (footnote omitted) (emphasis added); see also J. Finch, InTroduction to LeGal THEORY 34 (3d ed. 1979) (describing Hobbes as a natural law philosopher with a "patently political motive in using natural law to justify the necessity of an absolute ruler"). Despite the positivist "feel" of Hobbes's definition, and the fact that he makes natural law dependent on the existence of the state, Finch feels Hobbes must be labelled as a natural law philosopher. Why? Perhaps one of the reasons is that Hobbes had an explicit "normative" element in his theory-a purpose behind his definition-and positivists are supposed to eschew such luxuries.

82 See, e.g., O.W. Holmes, Collected Legal Papers 167-69 (1921). This is not to say that Holmes or any of the following authors saw their theories of law in the context I present them here. It is to say that the theories "make sense" in some intuitive, existential way within that context.

ss See, e.g., Kennedy, Toward an Historical Understanding of Legal Consciousness: The Case of Classical Legal Thought in America, 1850-1940, in 3 RES. IN L. \& Soc. 3, 9-17 (1980).

sf Formalist pronouncements are even more scarce than formalist practices. I con- 
jectivity, decisionmaking, and the proper limits of the judicial role. As a citizen, he might also want to know when state force was likely to be applied in support of a particular claim (an inquiry that might and might not depend on predictions of judges' behavior). More probably he would, like all of us, rely on all of these "definitions," sometimes sequentially and sometimes all together. How would a (purified, imperative) definition such as "law is the primary norm, which stipulates the sanction," him in any of these attempts to find what is and what is not the law of the state? Is there something that they would help him to do that Hobbes's theory, the lawyer's rule of thumb, or a first-year class in political theory would not do as well, or better? Would they help him do anything at all?

This is the secret at the heart of the invented tradition of positivism. By dispensing with the very notion of purpose, positivist theorists have carved out an unenviable territory for themselves. What is the positivist's answer to the question, "What is law?" It is not a political and legal theory such as Hobbes's, which puts forward an argument as to the conditions under which state power is justified and deduces a legal theory from the kind of compact that rational beings would accept. It is not a historical legal theory that describes the legal consciousness at some particular time or in some particular place. It is not a predictive theory that describes what judges and officials are likely to do. It is not an emancipatory theory that tries to expose the fetishism of the market, ${ }^{80}$ or the influence of the economic substructure, ${ }^{81}$ or the effects of racism or sexism on courts, or concepts, or patterns of thought. ${ }^{62}$ Nor is it a normative theory that puts forward arguments about what we should do based on Rawlsian ethics, ${ }^{63}$ or Posnerian effi-

tinue to regard H.L.A. Hart's idea of core and penumbral meanings of words as the foundation of a "loosened-up" formalism. See H.L.A. HART, supra note 9, at 121-32; Boyle, supra note 3, at 708-13. (1960).

see K. Llewellyn, The Common law Tradition: Deciding appeals

so See LAw's EMPIRE, supra note 14.

B7 See R. POSNER, Economic Analysis of Law (3d ed. 1986).

${ }^{b 8}$ H. Kelsen, General Theory of Law and State 61 (1945).

s9 H.L.A. HART, supra note 9, at 77.

so See Kennedy, The Role of Law in Economic Thought: Essays on the Fetishism of Commodities, 34 AM. U.L. REv. 939 (1985).

o1 See H. Collins, Marxism and Law (1984).

62 See, e.g., Burns, Law and Race in America, in The Politics of LAw 89 (D. Kairys ed. 1982); Freeman, Antidiscrimination Law: A Critical Review, in id. at 96; MacKinnon, Feminism, Marxism, Method, and the State: Toward Feminist Jurisprudence, 8 Signs 635 (1983).

ss See J. RAWLS, A Theory of Justice (1971). Ed Baker has produced the best examples of this general type of theory. See Baker, Counting Preferences in Collective 
ciency, ${ }^{64}$ or Sartrean contingency ${ }^{65}$ So what is it?

To answer this question we must look at what positivists think that they are doing. Positivists are, first and foremost, conceptualists. Their task is implicitly structured by two assumptions: first, that the highest form of knowledge about law can be gained through definition, and second, that the test of such a definition will be its ability to distinguish law from, or relate law to, those phenomena that are conceptually rather than ideologically, behaviorally, or professionally similar. Thus, positivist definitions are more or less explicitly designed to separate law from other normative systems (morals, religion), on the one hand, and threats or commands on the other.$^{66}$ Both these assumptions seem very implausible to me, for practical, methodological, and epistemological reasons. Definitional activity is practically an invitation for language to go on holiday.$^{67}$ Even if it were not, the focus on conceptual definition is unwarranted and on the few occasions when we are looking for conceptual maps of law, the positivist ones are of little use. But how did the positivists themselves see these apparently crippling defects in their own work?

Patterson may provide us with an answer. Earlier I quoted his comment that Hobbes "came close to" the imperative conception of law, but that his ideas still contained reference to "the question of the political justification of the state." theory this impurity has to be eliminated, or at least distinguished from the real task of positivism: defining law tout seul. Austin's work is purer, but even Austin's theory contains some references to political reality (e.g., his theory of sovereignty). ${ }^{60}$ Patterson notes that Kelsen dispenses even with this, a move that "simplifies the Austinian conception of law and makes sharper the division between the political philosophy of the state and jurisprudence (Kelsen's legal science)." actually seems like a good thing within the positivist/imperative tradition:

To many of Austin's followers and to lawyers engaged in

Choice Situations, 25 UCLA L. REv. 381 (1978); Baker, Outcome Equality or Equality of Respect, 131 U. PA. L. REv. 933 (1983); Baker, Property and Its Relation to Constitutionally Protected Liberty, 134 U. PA. L. REv. 741 (1986).

ot See, e.g., Landes \& Posner, The Economics of the Baby Shortage, 7 J. LEGAL STud. 323 (1978).

is See, e.g., Gabel, Intention and Structure in Contractual Conditions: Outline of a Method for Critical Legal Theory, 61 MinN. L. REv. 601 (1977).

so See H.L.A. HART, supra note 9; H. KELSEN, supra note 9.

or See L. WrTtgenstein, supra note 7.

es See supra text accompanying note 51 .

o9 See J. Austin, supra note 9, at 191-361.

70 E. Patterson, supra note 51, at 92. 
their professional work Austin's conception of sovereignty is a mere excrescence, since they take the government of their state as something given and are not called upon, as lawyers, to determine whether people are in a habit of obedience to it. However, it seems unnecessary to purge the conception of positive law of all factual connections with the society for which it is established and maintained. ${ }^{71}$

To me, that last sentence sounds wistful rather than ironic. In any event, I think Patterson has put his finger on the criteria for good positivist theory. Pure positivism comes close to pure emptiness. On the one hand, it is determined to differentiate itself from predictive, normative, and critical theories of law-theories that might play a role in legal practice. On the other hand, it shies away from political theories that venture to suggest that you cannot give a purely conceptual explanation of the obligation to obey law. This leaves it with the sterile middleground of "pure definition." No wonder Hobbes's theories are marginalized within the tradition. His theories are contaminated with such unimportant questions as human nature, the political justification of the state, the effect of one person's power on another-all of the things that the "sophisticated" positivists have managed to jettison. I hope that you see what I mean about Hobbes's ideas showing up the emptiness of the positivist tradition.

\section{Hobbes's Theory Is a Paradigmatic Example of How to Use Definitionalism for Political Ends Yet It Is EPISTEMOLOGICALLY INDISTINGUISHABLE FROM THE REST OF THE Tradition}

When the Parliament sate that began in April 1640 and was dissolved in May following, and in which many pointes of the Regall Power, which were necessary for the Peace of the Kingdome and Safety of his Majestye's Person, were disputed and denyed, Mr. Hobbes wrote a little Treatise in English, wherein he did sett-forth and demonstrate, that the sayd Powers and Rights were inseparably annexed to the Soveraignty, which soveraignty they did not then deny to be in the King; but it seemes understood not, or would not understand, that Inseparability. Of this Treatise, though not printed, many gentlemen had copies, which occasioned much talke of the Author; and had not his Majestie dissolved the

${ }^{71}$ Id. (emphasis added). 
Parliament, it had brought him in danger of his life. ${ }^{72}$

This quote from Aubrey shows one of the sides of Hobbes's work that is most important to this essay, both in terms of exploring the positivist tradition and in terms of showing the power of essentialist arguments. Hobbes was just too good at playing the definitionalist game. By appearing to deduce a set of incredibly powerful political arguments from the "very nature of" law and sovereignty, Hobbes provides an uncomfortable reminder that the definitional project is (a) based on a philosophical fallacy (the fallacy of reification), which (b) can have very potent (and somewhat dishonest) political effects. After all, it is well known that Hobbes was hot for centralized state power. $\mathrm{He}$ was a "political" theorist, implying that he is both non-objective and not primarily a jurisprude. If he claims to deduce all of his conclusions from the very definition of law itself, and if there appears to be no epistemological difference between his definitional "moves" and those of all of the other positivists, then maybe there is something wrong with definitionalism!

In this section, I work through Hobbes's definition of law in Leviathan. ${ }^{73}$ What follows is the greatest tour de force in producing political power out of definitions that I have ever come across. If you are averse to being manipulated by the massaging of words, then there is the same advantage to studying Hobbes on the relationship of language and power that there is to learning self-defense from a black-belt in karate. But the truly strange thing is that, as I will show in the next section, Hobbes does not believe in essences. How can one make a convincing argument about the necessary attributes of law if one does not believe in essences? Try to keep this question in mind as you read what follows.

I gave Hobbes's definition of law earlier, but it bears repeating.

Civill LAw, Is to every Subject, those Rules, which the Common-wealth hath Commanded him, by Word, Writing, or other sufficient Sign of the Will, to make use of, for the Distinction of Right, and Wrong; that is to say, of what is contrary, and what is not contrary to the Rule. ${ }^{74}$

Hobbes goes on to use two arguments that I described in an earlier paper $^{75}$ - sovereignty of facts and ordinary language ${ }^{76}$ - to support his

72 J. AUBREY, supra note 19 , at 151.

73 Leviathan, supra note 17 , at $312-35$.

74 Id. at 312 .

${ }^{78}$ See Critical Jurisprudence, supra note 5.

70 These arguments typically appear in the jurisprudential literature because of 
definition. He claims that his definition contains "nothing that is not at first sight evident." "We might doubt this, but he gives us no time to do so. He simply notes that "every man seeth" that laws are only laws to those whom they command. Two hundred years later, other theorists will turn this claim around, using the sovereignty of facts against him and arguing that a law is still a law even if it is not addressed to a particular person..$^{78}$ Of course, neither of these arguments makes sense unless you specify why we should choose to see law in the way the theorist suggests.

Hobbes also throws in a quick piece of apparent equivocation, noting that everyone should see that "[the] Lawes are the Rules of Just, and Unjust; nothing being reputed Unjust, that is not contrary to some Law."79 Of course one could pick this apart by a sovereignty of facts argument: one simply denies that Hobbes's theory adequately describes the world as it is because many unjust things are allowed by the law. But Hobbes is not really trying yet. $\mathrm{He}$ is saving his response to this claim until later. Predictably enough, it will be a sovereignty of theory argument; he will claim that natural law and, by implication, right and wrong, are defined by the law. One way of reading this is to suppose that he has to keep the two claims apart because otherwise the equivocation would become obvious. Another possible reading, and one that I will try to explain more fully later, is that Hobbes is doing something a

the contradiction involved in carrying out the essentialist project of defining law in an era when most theorists do not believe in essences. Sometimes the theorist will argue that a particular feature of our ordinary speechways tends to back up her theory-"Most people use the word 'law' to mean the rules presently laid down, not the rules as they should be according to some moral blueprint. This fact shows the basic truth of positivism and the basic fallacy of natural law." But on other occasions the theory will be held up as invalidating or disproving some ordinary usage- "International law is not really law because it has no centralized methods of enforcement." This is what I mean by equivocation in one's reliance on ordinary language.

I describe one side of the equivocation as a sovereignty of "facts" argument, the side in which the theorist uses common assumptions to back up the argument-"It would be ridiculous to say that private contracts were rules of law." Conversely, the sovereignty of theory argument is the one where the theorist uses the theory to chasten the facts-"A law without a penalty is not really a law."

Typically, theorists oscillate wildly between these arguments without explaining why the opposite argument would not be equally valid. As I will argue later, however, Hobbes at least offers an explicit transcendental purpose to underpin his argument, and a theory of language that demarcates a restricted role for ordinary language usage. See also Boyle, supra note 5 (describing similar pattern of repeated contradictions, stemming from unacknowledged fixation on essences, in international law arguments about sources, theory, and doctrine).

77 LeVIATHAN, supra note 17 , at 312.

78 See H.L.A. HART, supra note 9, at 22.

79 LeviathaN, supra note 17 , at 312 . 
little more sophisticated. His definition of law is not merely some piece of academic essentialism. He believes that his science of politics has shown a transcendental purpose behind law, the maintenance of order, which gives his definition its genuine metaphysical force. Thus, there can be no competing sources of normative authority in the state and, under any correct definition of law, right and wrong must be defined by the law rather than vice versa.

Now that the foundation has been laid down, Hobbes makes his pitch in earnest for authority. Notice the power of the definitional argument here. "And therefore, whatsoever can from this definition by necessary consequence be deduced, ought to be acknowledged for truth. Now I deduce from it this that followeth." deduces that the sovereign is the Legislator. "For the Legislator, is he that maketh the Law. And the Common-wealth only, prascribes, and commandeth the observation of those rules, which we call Law ...." And because the commonwealth can do nothing except by acting through some legislator, "therefore the Soveraign is the sole Legislator" and is "not Subject to the Civill Lawes." be deduced from the "fact" that it is impossible "for any person to be bound to himselfe; because he that can bind, can release; and therefore he that is bound to himselfe onely, is not bound."

Again, theorists two centuries later will claim that this is a mistake, triumphantly pointing out that members of parliament can be bound in their "private capacity" by the rules they make in their "public capacity." "Notice that if Hobbes is seen as defining law in the abstract, this "sovereignty of facts" argument shows him up as having made the conceptual mistake of ignoring the possibility of role differentiation in his definition. But there is obviously another way of looking at what he is doing.

The standard understanding of Hobbes as a political theorist is that he is trying to clarify our comprehension of the conditions under which order can be preserved. ${ }^{85} \mathrm{He}$ does this by "resolving" the state

\footnotetext{
${ }^{\text {so }} I d$.

81 Id. at 313 .

$82 I d$.

8s Id.

st See H.L.A. HART, supra note 9, at 42.

so See MacPherson, Introduction to LevirathaN, supra note 17, at 9-63 (discussion of the basic issues in Hobbes's thought). The main themes are covered well in most of the book-length treatments of Hobbes's ideas. See, e.g., D. GaUthier, The Logic of Leviathan (1969) (exploring Hobbes's moral and political philosophy); $M$. Goldsmith, HobBes's ScIence of Politics (1966) (arguing that Hobbes's legal, political, and religious theories are grounded in his understanding of science); HoBBes STudies (K. Brown ed. 1965); J. LAIRD, HobBes (1934) (biography, description of
} 
into power-seeking monads and then describing the "composite" that would result when they are put back together according to a plan that would be rationally acceptable to those same monads. ${ }^{86}$ If his premises were correct, then the role differentiation answer to "who governs the governed" would never work. If it does in fact work, Hobbes has been shown to have made a far more interesting mistake-the mistake of believing that there could never be strong enough negative consequences to prevent a governing class from arrogating to itself absolute power, or a subordinate class from using the contradiction in the system to destroy it.

Where did Hobbes go wrong? Did he, as MacPherson suggests, ${ }^{87}$ underestimate the power of bourgeois class, as opposed to individual interests? Did he underestimate the utopian power of the ideal of the rule of law? Did he concentrate so much on the egotistical aspects of human personality that he inevitably was going to produce "another beautiful theory, mugged by brutal facts?" Did he ignore the fact that the legalistic, role-differentiated functions that Sartre describes as one source of "bad faith"ss can become part of one's world, in such a way

intellectual milieu within which Hobbes worked and account of Hobbes's philosophy); F. McNeIlly, The ANATOMy of Leviathan (1968) (arguing that Leviathan is based on a more coherent analysis of human behavior than De Cive or The Elements of Law); S. Mintz, The Hunting of Leviathan (1962); R. Peters, Hobbes (1967) (reconstruction of Hobbes's asserted problems and his solutions to them); A. RoGow, Thomas Hobbes: Radical IN THE SERvice of Reaction (1986) (biography and intellectual history); J. WATKINS, HoBbES's SYSTEM OF IDEAS (1968) (concluding that Hobbes's political theory is implied by his philosophical ideas).

For a fascinating analysis of Hobbes's metaphysical ideas, which shows the parallels between Hobbes and the Aristotelian philosophy that he criticized, see T. Spragens, The Politics of Motion (1973). The same connections were subjected to a very different analysis by Strauss, see L. Strauss, The Political Philosophy of HOBBES (1936). I generally disagree with Straussian interpretations of political philosophy, but the book on Hobbes seems to me to be far more impressive than the rest of the genre. Spragens' analysis parallels my own at many points and I am considerably indebted to his book. My disagreements with his analysis of Hobbes's theory of meaning are explained later. See infra note 138.

so See D. GAUTHIER, supra note 85, at 1-5; T. SPRAGENS, supra note 85, at 145 58; J. WATkINS, supra note 85, at 52-55; MacPherson, supra note 85, at 25-30.

87 See MacPherson, supra note 85, at 55-56 (Hobbes's theory failed to take into account the "force of a cohesive bourgeois class.").

8s [A]mong the thousands of ways which the for-itself has of trying to wrench itself away from its original contingency, there is one which consists in trying to make itself recognized by the Other as an existence by right. We insist on our individual rights only within the compass of a vast project which would tend to confer existence on us in terms of the function which we fulfill. This is the reason why. man tries so often to identify himself with his function and seeks to see in himself only the 'Presiding Judge of the Court of Appeal,' the 'Chief Treasurer and Paymaster' etc.

J.P. Sartre, Being and Nothingness 485 (1956). Thus, the "legislator" and the 
as to put a veil over the unmediated appetites and aversions of Hobbes's hypothetical subjects? One thing is for sure-if one sees his mistake as a conceptual one, a failure to realize that legislators could be conceived of as both public and private, one will never get to deal with any of these questions. If you were to have suggested the role solution to Hobbes he probably would have said that human nature and the inherent attributes of power made it impossible. He was obviously at least partially wrong, but if we see his work as an abstract definition of law rather than a normative model of political reality, we will never be able to find out why.

So far Hobbes has struck several fairly powerful blows for the sovereign merely by "deducing" the consequences of his definition. He has indicated that there can be only one law-making sovereign, who must be supreme, who cannot be subject to its own laws, whose "artificiall reason" guides the laws, and who must be the final arbiter of any disputed interpretation. He has also mentioned in passing that right and wrong are defined by the laws, rather than vice versa. Next, Hobbes goes on to "deduce" that customary laws, or laws that arise from long use, really derive their validity from the sovereign's implicit agreement. "[I]t is not the Length of Time that maketh the Authority, but the Will of the Soveraign signified by his silence . . . ."88 This Will is, of course, revocable at any time because "the Judgment of what is reasonable, and of what is to be abolished, belongeth to him that maketh the Law, which is the Soveraign Assembly, or Monarch."80 As E.P. Thompson's work shows, customary rights were often considered one of the most powerful obstacles to centralized power, ${ }^{91}$ so this is an extremely important move.

The sovereign's authority is asserted over the normative remnants of time. Two pages later the same thing happens with space. ${ }^{92}$ Now we come to the third example of this normative colonialism, the argument

\footnotetext{
"citizen" may truly see themselves as different people caught in the same body.

so Leviathan, supra note 17, at 313.

Id. at 314 .

93 See generally E.P. Thompson, Whigs and Hunters: The Orugins of The BLACK ACT (1975) (The particular subject of the book is the bitter struggle over hunting rights between forest farmers and the landed gentry, with the former relying on customary entitlements and the latter on more formalized legal rights. A more general theme is that social norms can be turned against the ruling class, particularly at a moment when a decentralized customary regime is being replaced by a centralized statutory regime. Law appears, not as "the will of the ruling class," but as an arena for struggle, and this, of course, is exactly what Hobbes wished to avoid.).

${ }_{92}$ See id. at 315 ("Provinciall Lawes are not made by Custome, but by the Soveraign Power.")
} 
that carries the sovereign's writ into the transcendental dimension of natural law.

If customary rights, provincial laws, and the power of the judge are all subject to the final authority of the sovereign, and if the sovereign is not to be bound itself, what other potential sources of normative authority remain as challenges to central, secular state power? The most obvious answer is natural law. Natural law rhetoric could be used to attack and defend particular kings and even to attack and defend the institution of the monarchy itself. Hobbes wastes no time in "deducing" that "[t]he Law of Nature, and the Civill Law, contain each other, and are of equall extent." ${ }^{\text {"gs }}$ But, lest anyone think that he is putting them on a truly equal footing, he quickly explains which is the real container and which the thing contained.

For the Lawes of Nature, which consist in Equity, Justice, Gratitude, and other morall Vertues on these depending, in the condition of meer Nature . . . are not properly Lawes, but qualities that dispose men to peace, and to obedience. When a Common-wealth is once settled, then are they actually Lawes, and not before; as being then the Commands of the Common-wealth; and therefore also Civill Lawes: For it is the Soveraign Power that obliges men to obey them. ${ }^{94}$

Notice that the state has become a necessary condition for the law of nature and that the neat definitional twist in the last three phrases brings us back to Hobbes's original formulation, with its in-built claim that the civil law commands what is right and prohibits what is wrong. Absent state power there is no law of nature, merely a set of "qualities that dispose men to peace, and to obedience."95 We read this passage as cynical moderns. For us, the power of natural law discourse has been sapped, in part by the success of the positivist retelling of the tasks of jurisprudence. So it may be hard to realize how much of the tradition Hobbes was rejecting by defining natural law this way. Not only has he defined natural law so that it depends on the existence of the state for its normative force, he has also described it as consisting of peaceful, obedient qualities that sound more like the Boy Scout's oath, with its charmingly general instruction "obey other people," than the activist, egalitarian, (and rhyming) natural law put forward by groups like the Levellers. ${ }^{98}$

\footnotetext{
93 LeviathaN, supra note 17 , at 314 .

94 Id.

ss Id.

96 "When Adam delv'd and Eve span, Who then was the gentleman?" Portland
} 
Hobbes follows up this tour de force (d'etat) with something that sounds suspiciously like a claim that values are subjective and thus, that we need an authoritative source of normative judgment, complete with attached sanctions. ${ }^{97}$

For in the differences of private men, to declare, what is Equity, what is Justice, and what is morall Vertue, and to make them binding, there is need of the Ordinances of Soveraign Power, and Punishments to be ordained for such as shall break them; which Ordinances are therefore part of the Civill Law. The Law of Nature therefore is apart of the Civill Law in all Common-wealths of the world. Reciprocally also, the Civill Law is a part of the Dictates of Nature. ${ }^{98}$

So, natural law can hardly present a source of normative challenges to the authority of the sovereign; it not only depends on the civil law for

MSS. (H.M.C.) III, at 86, quoted in C. Hill, The World Turned Upside Down 35 (1972). This is surely the shortest argument yet discovered for the artificial quality of all social hierarchy.

${ }^{97}$ It is extremely easy to misread Hobbes's use of natural law ideas, particularly in this area. I mentioned above Professor Gray's claim that Hobbes makes two errors: "the fallacy of excessive realism" and "the compensating fallacy of excessive faith in natural law adjudication." See supra text accompanying notes 49-51. I have already dealt with the implications of Hobbes's skeptical theory of interpretation. As for his "excessive faith in natural law adjudication," Gray has this to say:

Apart from and because of the de facto relevance of reasonableness alone Hobbes thought that judges ought only to ask what solution would be reasonable. They should of course obey the sovereign's orders, reasonable or not. But short of the limiting case of an ad hoc command, they should consider only the requirements of universal natural law. The ideal society would be governed by natural law, subject to the consequences of that law's highest imperative, 'seek peace'-subject, that is to say, to the duty to obey one sovereign regardless of the justifiability of his commands. Judges should act as they would in an ideal society-do justice and equity-subject to being overruled by the sovereign. They should not excuse wrong decisions by pretending to be foreclosed by general instructions, which can never unambiguously dictate a concrete act.

Gray, supra note 45, at xi, xxxiii (interpreting $A$ Dialogue Between a Philosopher \& a Student of the Common Laws of England, supra note 20, and Hale's Reflections by the Lrd. Cheife Justice Hale on Mr. Hobbes His Dialogue of the Lawe, reprinted in $5 \mathrm{~W}$. HoldswORTH, A History OF ENGLISH LAW app. 3 (1945)). Gray is correct in saying that, when Hobbes argues for natural law adjudication it seems that he would want the judge to refrain from hiding behind the words of some general rule. But what would be the implication of this "natural law adjudication"? As I have tried to show, Hobbes would tell the judge to seek the decision which would be in the sovereign's best interest, because the sovereign's best interest is the concrete expressions of justice, equity, and the imperative "Seek peace." Natural law and "right reason" are reducible to raison d'état.

${ }^{98}$ Leviathan, supra note 17 , at 314 . 
its existence and its authority, it even contains a reciprocal obligation to obey the civil law. Hobbes tucks in any loose ends by coming back to the purpose at the heart of his definition of law, the purpose that he felt had been given transcendental authority by his science of politics and that thus made his definition more than empty scholastic verbiage. Hobbes, in other words, is giving us a definition that does not rely on the medieval essences of the "Schoolemen," for whom he felt such scorn, but instead, rests on an uncontroversial "purpose," which has been verified by a resolutive-compositive science of politics.

[T] he naturall Liberty of man, may by the Civill Law be abridged, and restrained: nay, the end of making Lawes is no other, but such Restraint; without the which there cannot possibly be any Peace. And Law was brought into the world for nothing else, but to limit the naturall liberty of particular men, in such manner, as they might not hurt, but assist one another, and joyn together against a common Enemy. ${ }^{99}$

Read in this light, Hobbes is more like a twentieth century process theorist such as John Hart Ely, who bases his ideas on a claim to have identified the uncontentious theory of American government, ${ }^{100}$ than he is like John Austin, (or at least, the received vision of John Austin) with his classificatory zeal for the "proper" naming of laws and things "improperly so called" laws. ${ }^{101}$ In fact, of all of the positivist legal philosophers discussed in this essay, Hobbes may be the closest to postrealist, purposive legal theory. To find out why this is so we must turn to his theory of language. Although Hobbes's ideas about language have received some attention from political theorists, they have been largely ignored by legal theorists--the very people who may have most to learn from his discussion of the interrelationship of political power and the use of essentialist philosophy.

\section{Hobbes's Theory of Language Seems to Challenge Definitionalism Because It Is Founded on a Critique of SCHOLASTIC ESSENCES}

At first, Hobbes seems to be an unlikely source for insights about,

99 Id. at 315 (emphasis added).

100 See J. ELY, DEMOCRACY AND DISTRUST 87 (1980) (arguing that the Supreme Court should adopt a "participation-oriented, representation-reinforcing approach to judicial review").

${ }^{101} \mathrm{~J}$. Austin, supra note 9, at 1 ("Laws proper, or properly so called, are commands; laws which are not commands, are laws improper or improperly so called laws."). 
and criticisms of, definitionalism. He says again and again that definitions are fundamental in the search for truth and seems to argue for spending more, rather than less time on refining them. But then he always adds a caution about the dangers they pose. I love the following example because of its charm, but also because it uses the kind of evocative language that we, with the eternal hubris of the present, have come to associate with modern, post-Wittgensteinian sermons on the limits of knowledge. ${ }^{102}$

For the errours of Definitions multiply themselves, according as the reckoning proceeds; and lead men into absurdities, which at last they see, but cannot avoyd . . . and at last finding the errour visible, and not mistrusting their first grounds, know not which way to cleere themselves; but spend time in fluttering over their bookes; as birds that entring by the chimney, . . . flutter at the false light of a glasse window, for want of wit to consider which way they came in. ${ }^{103}$

From this passage alone, it might appear that Hobbes is simply saying that one should be attentive to one's first premises. So we might conclude that jurisprudes should be very careful in formulating their definitions of law and that judges and lawyers should be wary in the use of syllogismatic reasoning lest they base their reasoning on some subtly "incorrect" definition of a legal term and then compound the error through a string of cases. That is part of his message, and the image of the jurisprudes "fluttering over their books" captures some of the compulsive and directionless aspects of positivism. But I think Hobbes is also saying something more subtle about the empowering and delusive aspects of language itself, something surprisingly similar to the critique of reification I introduced earlier. Here is one of his more famous passages on the subject:

Nor is it possible without Letters for any man to become either excellently wise, or (unless his memory be hurt by disease, or ill constitution of organs) excellently foolish. For words are wise mens counters, they do but reckon by them: but they are the mony of fooles, that value them by the authority of an Aristotle, a Cicero, or a Thomas, or any other Doctor whatsoever, if but a man."104

102 I was disappointed but unsurprised to find that Professor Spragens had already noted this similarity. See T. SPRAGENS, infra note 85 , at 93-94 n.25.

10 Leviathan, supra note 17, at 105-06.

106 Id. at 106. 
Again, one might almost think that is Wittgenstein talking. Language is both a tool and a trap, a potential source of mental cramps as well as of excellent wisdom. The philosopher's role is to guard against the bewitchment of the intelligence by language. There are more similarities than that. Hobbes's ideas have the same rich, contradictory feeling as those of Wittgenstein. There are the same tensions between problem solving and grand speculation, between an intentionalist theory of meaning and ordinary language usage, and there are similar reconciliations-grand speculation redefined as problem solving, intention emerging through common usage and sometimes revolting against it. Finally, there is the same episodic attention to an issue I plan to discuss more fully sometime in the future, the power of language and the language of power. But to get to all of this, we have to start at the beginning, which, as I see it, is almost at the end of Leviathan.

It is, appropriately enough, in the much neglected section on the Kingdome of Darknesse, ${ }^{108}$ that Hobbes gives one of the clearest explanations of his dissatisfaction with the idea of essences. After a fairly complicated discussion of some of the terms of art beloved of scholastic philosophy and theology, he offers the following justification of this apparent digression to his perplexed reader:

But to what purpose (may some man say) is such subtilty in a work of this nature, where I pretend to nothing but what is necessary to the doctrine of Government and Obedience? It is to this purpose, that men may no longer suffer themselves to be abused, by them, that by this doctrine of Separated Essences, built on the Vain Philosophy of Aristotle, would fright them from Obeying the Laws of their Countrey, with empty names; as men fright Birds from the Corn with an empty doublet, a hat, and a crooked stick. ${ }^{108}$

Hobbes is certainly not restricting himself to linguistic essences here. The discussion focuses on the link between Catholicism and Aristotelian thought, with excursions into the taste of bread, the location of the soul, and the source of virtue. But I think that the quote illuminates two important points in our analysis of the power of linguistic reification, points that I will try to substantiate in what follows. First, as I hope subsequent quotations will show, Hobbes realizes that the idea of essences involves the same epistemological error whether the essences are supposed to be of words, objects, or souls. Second, Hobbes was not

${ }^{105}$ Id. at $627-715$.

108 Id. at 691 . 
only critical of scholastic method because he thought its reliance on essence was "a mistake," he thought the scholastic essences doctrine could have a powerful and malevolent political effect. His criticism of essences was designed specifically to counter this effect-to stop this "Vain Philosophy" of "Separated Essences" from frightening citizens out of their obedience to the "Laws of their Countrey, with empty names."10z Positivists, who have erected their discipline on something suspiciously similar to this "Vain Philosophy" of "Separated Essences" might do well to consider his criticisms. And, because every legal argument is, in a sense, the wringing of political power out of the meanings of words, we cannot consign his message to the softly irrelevant fringe of academic jurisprudence.

If all of this is true, and Hobbes is criticizing the idea of essences because of its philosophical errors and its political consequences, we are faced with three fairly perplexing questions. First, what theory of language is he going to put in the place of the idea that words express the essences of objects? Second, what is he, himself, doing when he defines "not . . . what is Law here, and there; but what is Law."108 Which leads us to the third question: How does his theory of language fit his legal theory? Specifically, how can it fit in with both the attempt to define the meaning of law and then deduce from it "what follows as a matter of necessary consequence," and with the claim that all laws have need of interpretation because of the "divers meanings of words." If all words have "divers meanings," then his definition of law is one among many "correct" definitions. And if that is true, then how can Hobbes get away with the project we looked at earlier: the attempt to "deduce" from the definition, as a matter of "necessary consequence," that all normative systems have their basis in the sovereign?

The first two questions may be the hardest ones. Hobbes has generally been seen as a radical nominalist, ${ }^{109}$ that is, someone who believes that the only thing shared by a general class of phenomena denoted by a single name (i.e., games, chairs) is the name itself.

[S]ome [names] are Common to many things; as Man, Horse, Tree; every of which though but one Name, is nevertheless

107 LeviathaN, supra note 17 , at 691.

108 Id. at 311-12.

109 See T. SPRAGENS, supra note 85 , at 87 ("The relationship of the name to the object is, in fact, dissolved by Hobbes, who considers names to be 'signs of our conceptions' and manifestly 'not signs of the things themselves.' ") (quoting W. MOLESWORTH, 1 The ENGLISH Works of ThOMAs HobBes 17 (1966) [hereinafter EnGLISH WoRks]); Krook, Thomas Hobbes's Doctrine of Meaning and Truth, 31 PhILosophy 3-22 (1956); Oakeshott, Editor's Introduction to T. HOBBEs, LEvIATHAN at xxiv (M. Oakeshott ed. 1946). 
the name of divers particular things; in respect of all which together, it is called an Universall; there being nothing in the world Universall but Names; for the things named, are every one of them Individual and Singular. ${ }^{110}$

And because words are the only Universals it is obvious that

to put genus and species for things, and definition for the nature of any thing, as the writers of methaphysics have done, is not right, seeing they be only significations of what we think of the nature of things....

....

.. . For definition is not the essence of any thing, but a speech signifying what we conceive of the essence thereof .....111

We do not attach the name to the class of phenomena by looking for an essence of gameness or chairness in each game or chair. ${ }^{112}$ To be sure, all games do have one common property: they are all called "games." This is a tidy and attractive answer, although, if you have not encountered it before, you may have to think about it for a while to see the problems that it raises. If we say the same thing about "law," then Hobbes's claim that all laws must have the sovereign-centered qualities described in his definition seems ridiculous. If names are the only universals, the only thing that all laws share is the name "law"? After Hobbes renounces the idea of essences, it is hard enough to see how he can maintain the definitional-deductive side of his jurisprudence, but when he replaces it by an extreme version of nominalism the task seems impossible. Anyway, where do these "names" come from? Is it totally arbitrary that this set of phenomena, rather than some other set, ends up being called "games"? And what if we are in doubt as to whether something really is a "game," really is a "law"? We cannot give a nominalist answer to the question "What is it?" because we do not know what it is called.

I think the answer to all of these questions lies in Hobbes's theory of meaning, a theory which can be seen quite clearly in the following

110 Leviathan, supra note 17 , at 102.

111 ENGLISH WORKs, supra note 109, at 21, 60.

112 See L. WITTGENSTEIN, supra note 7, at 31 .

Consider . . . the proceedings that we call "games." I mean boardgames, card-games, ball-games, Olympic games, and so on. What is common to them all?-Don't say: "There must be something common, or they would not be called 'games' . . . For if you look at them you will not see something that is common to all, but similarities, relationships, and a whole series of them at that. 
throwaway remark, made as a preface to one of his chapters on biblical interpretation. What is more, it is an answer that may actually allow him to reconcile his nominalism with his definition of law. "Seeing the foundation of all true Ratiocination, is the constant Signification of words; which in the Doctrine following, dependeth not (as in naturall science) on the Will of the Writer, nor (as in common conversation) on vulgar use, but on the sense they carry in the Scripture . . .."113

There are no essences, and the only thing shared by a general class of phenomena that is denoted by a general name is the name itself. But names can come from different sources and, although the cardinal rule in "all true ratiocination" is to keep the meanings of words constant, one must first know the correct source. In an earlier essay I pointed out the difficulty of reconciling two different sides of language use. ${ }^{114}$ Does meaning come from the intention of the user-"Words mean what I want them to mean"-or does it depend on the linguistic practices of the society? If the former is the case, what are the limits of this purposive idea of language? How far can we go? If the latter, is it ever proper to change the meaning of a word or does normal usage imply normative correctness? ${ }^{115}$

Hobbes is putting forth a sophisticated theory of meaning that allows for different practices of signification depending on the kind of activity in which the speaker or writer is engaged. In common conversation, it would be unwise to depart radically from the ordinary language meaning (the vulgar use) of a word. But in "naturall science," when philosophers are constructing theories about the world, they cannot be tied to vulgar usage. The meaning of a word must come from the "will of the writer," so that the philosopher can fashion words into tools capable of resolving a particular problem. Remember that "words are wise mens counters, they do but reckon by them: but they are the mony of fooles."116 What is the difference between counters and money? Money is (thought to be) intrinsically valuable; we might think that it has its own meaning. Counters, on the other hand, are only valuable insofar as they allow you to perform some task. They have whatever meaning we choose to give them (think of assigning value to different colored poker chips). ${ }^{112} \mathrm{I}$. think that Hobbes is saying that,

11 Leviathan, supra note 17 , at 428 (emphasis added).

114 See Boyle, supra note 3.

I1s See id. at 708-15, particularly n.79 (Common usage theorists "frequently move from claims about 'normal' usage to claims about normatively correct usage without realizing the extent to which this involves them in the naturalistic fallacy.").

136 Leviathan, supra note 17, at 106.

117 This thought can be pushed even further. Actually both money and counters require us to invest them with meaning and value, something which is much harder to 
when we are engaged in "naturall science," we should have the same freedom to assign meaning-to shape the meanings of words according to the tasks in which we are engaged.

So the answers to the first two questions I posed-what theory of language Hobbes puts in place of essentialism and what exactly Hobbes is doing, when he himself defines law-are rather complicated. Hobbes rejects the scholastic idea that a general term (such as "law") signifies a common property, or essence, in each of the phenomena it describes. I asked what theory of language he offered instead of the scholastic one. The answer seems to be that he is a nominalist; but if that were true, one would expect his jurisprudence to rest on the idea that the only "property" that all "laws" share is that they are all called "laws." Needless to say, this would not fit very well with the project of deducing, from the unchanging definition of law, the normative primacy of the sovereign. But Hobbes is more subtle than this.

How do names get attached to phenomena, if not by tracing the outlines of some essential feature? Hobbes gives us two answers. In everyday speech, they get attached by common ("vulgar") usage, says Hobbes, apparently reserving ordinary language philosophy for ordinary conversations. When theorizing, they are attached according to the will of the writer. In either case, we should keep the meaning of our terms constant. The person who does not do so will end up "entangled in words, as a bird in lime-twigges; the more he struggles, the more belimed." Which is all very well, but how is the theorist to know the "correct" meaning, the meaning that is to be kept constant if the "ratiocination" is to proceed correctly? It is not much help to say that the meaning comes from the philosopher's will; how is a poor philosopher to know what to will?

We can rule out some answers. The philosopher cannot claim that

do to grubby pieces of green paper than to cowrie shells. But, the "meaning" of money involves a general, societal, and authoritative infusion of meaning-a collective idolatry that is hidden from everyday reflection. (Compare the "meaning" of a banknote in Weimar Germany with the "meaning" you discern when you look in your wallet to see if you have enough for lunch.) The meaning of counters, on the other hand, is infused according to private, personal, and idiosyncratic decisions. So the distinction is not "inherent meaning" versus "purposive meaning," but public, collective and generally unconscious, versus private, individual and generally conscious. This reading would make Hobbes's analogy even more complicated, because it would indicate that he is defending a pragmatist, purposive theory of language against a theory that locates the meaning of words in the external approval of some "authority," be it societal (as in our common speechways) or, as Hobbes specifically says, the authority, accorded to past thinkers. "[B]ut they are the mony of fooles, that value them by the authority of an Aristotle, a Cicero, or a Thomas, or any other Doctor whatsoever, if but a man." Leviathan, supra note 17, at 106.

318 LEVIATHAN, supra note 17, at 105. 
there is some essence to which her usage of terms must be faithful. That would just lead us back into Hobbes's nominalist attack on scholastic philosophy. She cannot rely on the authority of past definitions, even those backed up "by the authority of an Aristotle, a Cicero, or a Thomas, or any other Doctor whatsoever, if but a man."119 In fact, she must be ready "to examine the Definitions of former Authors; and either to correct them, where they are negligently set down; or to make them" herself. ${ }^{120}$ And as was pointed out earlier, she need not rely on "vulgar use" if she is engaged in "naturall science." This, in turn, seems to indicate that when Hobbes is prescribing for theorists, as opposed to conversationalists, he deserts (or expands on) the pure nominalist idea that definitions are explorations of "truths constituted arbitrarily by the inventors of speech."121

Thus, received wisdom, ordinary language use, and transcendental essences are all unavailable as sources of true meaning. Which leaves us with . . . ? It leaves us with science. Or, to be more accurate, there are good reasons to see Hobbes as one who was relying on the scientific method (as he understood it) for his ultimate epistemological backstop. Aubrey gives us the most notable comment on Hobbes's attraction to one component of his "scientific method," geometry.

He was 40 yeares old before he looked on Geometry; which happened accidentally. Being in a Gentleman's Library, Euclid's Elements lay open, and 'twas the $47 \mathrm{El}$. libri I. He read the Proposition. By $G \longrightarrow$, sayd he, (he would now and then sweare an emphaticall Oath by way of emphasis) this is impossible! So he reads the Demonstration of it, which referred him back to such a Proposition; which Proposition he read. That referred him back to another, which he also read. Et sic deinceps [and so on] that at last he was demonstratively convinced of that trueth. This made him in love with Geometry. ${ }^{122}$

It did, indeed. In fact, it seems to be one of the factors that led him to have such a high regard for clarity in definition, a regard he did not think was shared by others.

[T] ]here can be nothing so absurd, but may be found in the books of Philosophers. And the reason is manifest. For there is not one of them that begins his ratiocination from the Def-

\footnotetext{
119 Id. at 106.

$120 \mathrm{Id}$. at 105

1911 ENGLISH WoRKs, supra note 109, at 37.

$132 \mathrm{~J}$. AUBREY, supra note 19, at 160.
} 
initions, or Explications of the names they are to use; which is a method that hath been used onely in Geometry; whose Conclusions have thereby been made indisputable. ${ }^{123}$

Although this demonstrates the influence of mathematical thought on Hobbes's work, it seems only to tell us that our definitions should be clear, without telling us what those definitions should be. Or does it? C.B. MacPherson puts it nicely: "But something more than his discovery of Euclid was needed before he could apply anything like a geometrical deductive method to politics. What was needed was a basic hypothesis about the nature of things, which could embrace the actions of men in society and their relations with each other . . ."124 The missing element came from the work of Galileo.

When he was at Florence, he contracted a friendship with the famous Galileo, whom he extremely venerated and magnified .... They pretty well resembled one another as to their countenances .... [A]nd had both a consimilitie of Fate, to be hated and persecuted by the Ecclesistiaques."125

And Hobbes confirms the importance of Galileo's method on his own science of politics.

Galileus in our time was the first that opened to us the gate of natural philosophy universal, which is knowledge of the nature of motion. Lastly, the science of man's body, the most profitable part of natural science, was first discovered with admirable sagacity by our countryman Doctor Harvey. Natural philosophy is therefore but young; but civil philosophy is yet much younger, as being no older (I say it provoked, and that my detractors may know how little they have wrought on me) than my own book $D e$ cive. ${ }^{126}$

Hobbes seems to have been fascinated by two components of Galileo's method. The first is the idea of motion, which becomes Hobbes's master metaphor for cause, be it physical, societal, or mental. ${ }^{127}$ There

128 Leviathan, supra note 17 , at 113-14.

124 MacPherson, Introduction, supra note 85, at 18.

$125 \mathrm{~J}$. AUBREY, supra note 19, at 157.

1382 ENGLISH WoRKs, supra note 109 , at 8.

127 Notice that the other person mentioned is Doctor Harvey, another pioneer of the explanation of motion. He, as Aubrey so calmly puts it, was the "Inventor of the Circulation of the Bloud." J. AuBREY, supra note 18, at 127. Harvey was less critical of Aristotelian philosophy, however, than Hobbes. He told Aubrey, for example, to "goe to the Fountain head, and read Aristotle, Cicero, Avicenna, and did call the Neoteriques shitt-breeches." Id. at 128-29. 
is a second component to Hobbes's indebtedness to Galileo. How does one understand motion? Let Hobbes explain:

[E]verything is best understood by its constructive causes. For as in a watch, or some small engine, the matter, figure, and motion of the wheels cannot be well known, except it be taken insunder and viewed in parts; so to make a more curious search into the rights of states and the duties of subjects, it is necessary, I say, not to take them insunder, but yet that they be so considered as if they were dissolved. ${ }^{128}$

And in this manner, by resolving continually, we may come to know what those things are, whose causes being first known severally, and afterwards compounded, bring us to the knowledge of singular things. I conclude, therefore, that the method of attaining to the universal knowledge of things, is purely analytical. ${ }^{128}$

So science rests on the idea of taking things apart, or "resolving" them and then, as Galileo had done, putting those parts together so as to describe the motion of the whole. Once we have taken the Gallilean step of imagining the smallest forces that explain the phenomenon, we can turn to our Euclidean mode of "ratiocination from definitions." I think that this vision of science explains the connection that Hobbes saw between science and the making of definitions.

For REASON, in this sense, is nothing but Reckoning (that is, Adding and Subtracting) of the Consequences of general names agreed upon, for the marking and signifying of our thoughts ....130

The Light of humane minds is Perspicuous Words, but by exact definitions first snuffed, and purged from ambiguity; Reason is the pace; Encrease of Science, the way; and the Benefit of man-kind, the end. ${ }^{131}$

If all of this is right, it would explain how a "radical nominalist" can make an apparently definitionalist argument about the necessary qualities of law. The argument would go something like this. Following our Gallilean-Euclidean method, we resolve the state into its smallest comprehensible element-the citizen. Then we resolve the citizens' motivations into their smallest comprehensible units-appetites and

128 2 ENGLISH WORKs, supra note 109, at xiv.

1201 ENGLISH WORKS, supra note 109, at 69.

180 Leviathan, supra note 17 , at 111.

132 Id. at 116. 
aversions. This part of the story is familiar. Analysis of these appetites and aversions leads to the conclusion that human desires are basically opposed because the measurement of my effective power (the ability to satisfy my appetites for "some future apparent good"132) is the extent to which my power exceeds that of others. No agreement among citizens can palliate the negative consequences of this existence, because as soon as it was in my best interests, I would break the agreement. "Covenants, without the Sword, are but Words."133 Perceiving all of this, however, as a rational actor I would be willing to give up this state of affairs if I could be assured of peace, that is, if I could be assured that everyone else will be as constrained as I am. And, of course, only the Leviathan, the strong state, can guarantee me all of this. So we have "composed" our resolved elements back into a vision of what a properly functioning state would look like. Now, and only now, does it make sense to define law. And how do we do this? Not by grasping some preexisting essential conceptual component of legality. Not by wandering our everyday speechways playing fast and loose with the difference between normal usage and normatively correct usage. Not even by relying on the arbitrary names bestowed by time and authority. A resolutive-compositive science of politics gives us the true purpose of law, and thus the true definition of law. ${ }^{134}$

[T] he naturall Liberty of man, may by the Givil Law be abridged, and restrained: nay, the end of making Lawes, is no other, but such Restraint; without the which there cannot possibly be any Peace. And Law was brought into the world for nothing else, but to limit the naturall liberty of particular

182 Leviathan, supra note 17 , at 150.

138 Id. at 223.

184 This points out the difference between my account and that of Professor Spragens. How can Hobbes carry on his definitional project given his critique of essences? Professor Spragens feels that the whole weight of the theoretical edifice is thrown onto Hobbes's nominalist theory of meaning - which clearly is unable to bear the burden. I have argued that this is not entirely the case because Hobbes's situational theory of meaning allows him to grant the theorist freedom from the prison-house of a language in which names are attached arbitrarily. Thus the theory of meaning can be plugged back into the scientific/compositive-resolutive method, the same method which gives us the fundamental purpose, or epistemological standpoint, for Hobbes's definitions. For other interpretations of Hobbes's theory of meaning, see M. GoLDSMrTH, supra note 85, at 8-13; J. WATKINS, supra note 85, at 138-62; Krook, supra note 109, at 3-22; Oakeshott, supra note 109, at xxiv. To me it seems that all of these accounts also underestimate the contextual quality of Hobbes's theory of "true ratiocination" and "constant signification." In other words, they fail to recognize that in "natural science" signification depends on "the will of the writer," in common conversation on "vulgar use," and in theology on "the sense that [words] carry in the Scripture." LEvIATHAN, supra note 17 , at 427 . 
men, in such manner, as they might not hurt, but assist one another, and joyn together against a common Enemy. ${ }^{135}$

So, when contemporary theorists see Hobbes's theory as containing unwanted, "nonlegal" elements, they fail to realize that he was operating with a much more sophisticated epistemology behind his definition than they have behind theirs. The definition of law had to be tied to the theory of the state; to the question of the political justification of the state or of "sovereign power"; and thus to the "scientific" theory of appetites and aversions and to the fundamental purpose that that theory revealed. Otherwise it would not be a definition, but a "Vain Philosophy" of "Separated Essences." In order to define law without such a purpose, we would have to make an error that Hobbes knew very well. "The fifth [cause of absurd assertions is] the giving of the names of accidents [phenomenological qualities], to names and speeches; as they do that say, the nature of a thing is its definition; a man's command is his will; and the like."138

If we translated Hobbes's fifth cause of absurd assertions into modern philosophical language, we might say that it was (at least partially) a critique of reification. We have fancy terms for the errors that Hobbes described. We have learned a lot. But jurisprudence is still conceived as being the search for the nature or definition of law. H.L.A. Hart's theory of interpretation is concerned with the core meanings of words, ${ }^{137}$ and positivists can still argue that "lawyers engaged in their professional work . . . take the government of their state as something given." ${ }^{138}$ All of this tends to maintain the idea of a purified legal science that can separate the fields of political and legal theory by separating the definition of law from the purpose that it serves. So perhaps we have not learned very much after all.

\section{There Is a Revealing Connection Between Hobbes's Theory and Gurrent Debates About Legal Interpretation}

So far, I have been arguing that Hobbes is much more than a legal theorist, and that his theory challenges positivist jurisprudence in all the ways described in my verbose section headings. Now I want to reverse myself; to consider Hobbes as "merely" a jurisprude. For me, one of the most interesting things about rereading Hobbes's work as a legal theorist is the precise connection between his theory of interpretation

1s8 LeviathaN, supra note 17 , at 315 .

$138 I d$. at 114 .

${ }^{137}$ H.L.A. HART, supra note 9, at 121-32.

$1 s 8$ E. PatTerson, supra note 51 , at 92. 
and our current debates about the same subject. All laws need interpretation because of the "diverse meanings of words," and this interpretation must be guided by some higher principle. So says Hobbes, and a long line of contemporary Anglo-American legal theorists would agree. They would differ, as I pointed out earlier, about what that higher guide to interpretation should be. It has taken a long time, but it seems that even orthodox legal theorists are coming to agree with Hobbes that "reason" alone cannot do the trick. ${ }^{13 \theta}$ Not that Hobbes is against reason. He just wants to know, "Whose reason?" The contemporary answer seems to be that we should rely on the collective wisdom of the legal profession and of legal institutions, imbued as they are with all kinds of painfully gleaned experience, and hedged around with all kinds of real, if unspecifiable, professional, communal, and aesthetic constraints. ${ }^{140}$

This is not an unfamiliar theory. Throughout the twentieth century, belief in the essential forms of law, science, art, and language has been fading. In its place there has been an increasing reliance on the views of the "relevant community of experts." The criterion of truth and interpretation passes from The Scientific Method to micro-communities of scientists, from the Essential Meaning of Words to ordinary language usage, from the Forms of Art to the artistic community, from The Novel, to the author, to the readers, and then, alas, to the literary critics. ${ }^{141}$ Stanley Fish's interpretive community of professionals ${ }^{142}$ and Ronald Dworkin's comparison of law to a (soft-porn) chain novel ${ }^{143}$ do much the same thing, albeit a little belatedly and with emphases that seem (to Dworkin and Fish) to be very different.

In looking at the process by which strong essentialist claims are renounced in favor of a reliance on the opinion of a professional community, we should remember that it is not a phenomenon unique to the twentieth century. Hobbes was faced with the idea that we should defer to the interpretation of the professional community of lawyers and he did not like it. In large part, his concern was that lawyers might set themselves up as possible challengers to the sovereign, something that we may be a little less worried about, "hyperlexis" notwithstanding. But he also had strong theoretical objections on other grounds. In fact

198 See LAw's EMPIRE, supra note 14.

140 See supra note 3.

141 See authorities cited supra note 3.

142 S. Fish, supra note 38, at 322-37.

143 LAw's EMPIRE, supra note 14, at 228-39. In the most recent version of the chain-novel analogy, Naked Came the Stranger has been replaced by the Bible, soap operas, and the Odyssey. The first and third seem like shaky analogies and the second does not do much for the dignity of law's empire. 
he spends a large part of the Dialogue Between a Philosopher and a Student of the Common Laws of England ${ }^{\mathbf{1 4 4}}$ elaborating on his belief that neither the professional community of lawyers nor their "product," the artificial reason of the common law, is capable of resolving problems of interpretation.

His arguments are the same ones that I mentioned earlier. Recourse to "private reason" would lead to contradiction in the laws. "Long study may . . . confirm erroneous Sentences." We need a source of decision that stands above the "disputes of private men."145 Much of the recent scholarship has consisted in restating these arguments. But there is a more important theme that emerges from Hobbes's writing, a theme that should speak to us, appeal to us, even if we do not feel anarchy to be either as close or as dangerous as he did. Hobbes fears that social decisionmaking will be carved up into a multitude of private satrapies, and that is a fear which we can, and should, share.

What if we do throw away all pretensions to the upper case versions of our disciplines? What if we say that law is what the legal community says it is, that science is what scientists are willing to accept, that art is what you can get away with in front of your artistic peers? Personally I think these arguments have just the same problems as the ones they replace. The questions "what is art, law, science?" are simply converted to the question of who is in the relevant community, with all the same problems of indeterminacy, political tilt, and infinite regress. But even if this were not true, the current vogue for replacing essentialism with expert opinion raises the specter of donating public decisionmaking to private groups.

If we adopt the professional community theory of "What is law," is it too cynical to expect that the legal profession will go on claiming to the outside world that lawyers are neutral technicians merely working with the brute objectivity of the law? And if the story for external, public relations, distribution continues to rely on a sort of crude formalism, will the sophisticated defenders of the profession still try to silence their internal critics by claiming to be a trustworthy community of truth-seekers who actually create the reality which they claimed, a moment ago, to be describing? A world in which political questions become technical questions, and in which the legal profession "has it both ways"-Langdell to the outside world and Kuhn to the inside-is not a world that appeals to me. And if it seems strange that Hobbes, guardian of order that he was, prompts such thoughts, remember that, at

14 T. HobBes, supra note 20.

14 See Leviathan, supra note 17 , at 316-17. 
least where philosophers and lawyers were concerned, he was also a virulent anti-professional.

\section{CONCLUSION}

I hope that this essay gives some sense of the hundreds of discrete insights into law, language, and definition that we tend to neglect when we think of Hobbes only as the apologist for strong central government (which he certainly was). In the conclusion I want to concentrate on only one of the themes of the essay: the light that Hobbes throws on the line between legal and political theory.

Hobbes shows us a lot about the process of policing the boundary between legal and social theory. He helped me, at least, to understand the eagerness with which positivists have attempted to separate themselves from predictive, historical, or argumentative maps of law, on the one hand, and political theories of obligation and justification on the other. The first way that Hobbes helps us understand the positivist enterprise of defining law is by exploring the linguistic error on which much of it is based. "A great muddle . . . resulted because people thought there was something in common between all the things called 'good'."146 That is Wittgenstein talking, but it could just as well be Hobbes, telling us that the only thing shared by all the phenomena grouped under a single name is the name itself.

The second way in which Hobbes helps us (and helps us in a way that Wittgenstein, for example, does not) is by showing that the use or definition of essences in an argument is not just a philosophical "mistake." Hobbes has a very concrete reason for engaging in such philosophical "subtilty" as a critique of linguistic, metaphysical, and theological essentialism in a work where he

pretend $[\mathrm{s}]$. . . nothing but what is necessary to the doctrine of Government and Obedience[.] It is to this purpose, that men may no longer suffer themselves to be abused, by them, that by this doctrine of Separated Essences built on the Vain Philosophy of Aristotle ... would fright them from Obeying the Laws of their country with empty names . . . ."147

And, of course, that is not the only use to which one can put an argument from essences; arguments that justify the oppression of one group by another frequently depend on claims about the essential qualities of

148 Wittgenstein's Lectures, CAMbridge 1932-1935, at 45-46 (A. Ambrose ed. 1979).

147 Leviathan, supra note 17 , at 691 . 
both dominator and dominated. This is a fact that women, Jews, Blacks, and members of the working class have all learned to their detriment.

The point that I am trying to make is that claims about essences manage to make a value judgement without seeming to do so. They are more than just "mistakes" because they are not located in a heaven of legal concepts. They are part of a world in which people say, "X group lacks the essential qualities of human beings and, therefore, the rules of conduct toward humans do not apply," as well as saying "Y lacks the essential qualities of a law and, therefore, you need not obey it." These line-drawing definitionalist arguments may produce results we like or hate. They may be used consciously to some deep end, or the arguments may take over their practitioners, as I believe is the case with positivist jurisprudence. In either case, they are dangerous. If we need Wittgenstein to warn us against mental cramps and the bewitchment of the intelligence by language, we need Hobbes to remind us what you can do with the bewitchment of language.

The third way in which Hobbes helps us is perhaps the simplest, perhaps the most complicated, way of all. He tells us to avoid the predicament of the definitionalists, "fluttering over their bookes; as birds that entring by the chimney, and finding themselves inclosed in a chamber, flutter at the false light of a glasse window, for want of wit to consider which way they came in."148 And he does so by example, in a theory that tries to escape the trap by tying his definition of law to the uncontroversial purposes that are revealed by a science of politics. Perhaps the single most important thing that we have to learn from Hobbes is the idea that his definition serves a purpose and that, unless we can get around the critique of essences, our definitions also have to be guided by a purpose.

This seems to collapse the line between legal and political theory because, if you cannot define "what law really is," but instead must choose your vision of reality, all definitions become subject to the test of morality. It may be the morality of giving an instrumental-predictive definition of the law to your client or the morality of a definition that deduces the existence or nonexistence of legal obligation from conceptual components, but it is a "morality" nonetheless and not a world of pure concepts confronted by a disinterested observer.

Before we ask whether Hobbes, himself, "succeeded" and inquire into the morality of his definition, we should ask, "Should our jurisprudence follow the model of his?" Is the only correct definition of law one

148 Id. at $105-06$. 
that explains the justification for state power and the obligation to obey the laws? It certainly looks both more interesting and more methodologically sound than the attempt to produce a reductionist, conceptual exegesis for no particular purpose at all. And, for those reasons among others, trenchant critics such as Philip Soper have argued that we should desert positivism for a legal theory that focuses on moral and political obligation, in his case a theory that claims: that "Legal systems are essentially characterized by the belief in value, the claim in good faith by those who rule that they do so in the interests of all."148

This theory at least tries to fulfill some real purpose. It tries to answer the question, "If I wanted to know when I should obey a rule of law, what kind of definition of law would you give me?" And it may be worthwhile in a way that Kelsen's concept splitting is not, although personally, I am skeptical that any formulation of the obligation to obey could be arrived at that was neither tautological nor "void for vagueness." But that still leaves open the question of whether the real essence of law can only be described in terms of the obligation to obey. I think not, for the obvious reason that this is just moving the error back one stage. We realize that there is no essence to law, but instead a multitude of realities, each evoked by a particular context and purpose. So what do we do? The wrong answer, I believe, is to claim that there is one essential purpose, that rules supreme, from which we can contemplate the true reality of law. This is the "mistake" that Hobbes makes in his fixation on order.

In the end, Hobbes's theories suffer from many of the same problems as those of the legal process theories of the twentieth century. Both are founded on the rejection of essences, the process theorists because they had absorbed the critiques that the legal realists had made of formalism, and Hobbes because he had a strong aversion to the "Vain Philosophy" of "Separated Essences" that was peddled by "deceived, or deceiving Schoolemen."180 Lacking an essentialist philosophy, both Hobbes and the legal process theorists turned to the idea of uncontentious purposes. If they could find the purpose behind a rule or a state or an institutional structure, they could continue to theorize, in almost the same way as the group against whom they had reacted, but by whom they had been so influenced. But the "purpose" never could be quite broad enough; it always seemed as though there were other purposes that were equally valid. Then there was the problem of where you got your purposes from. Hobbes claimed that his were immanent

119 P. SOPER, A THEORY OF LAW 55 (1984) (arguing that current positivist theories of law are misdirected in that they divorce legal theory from moral theory).

160 Leviathan, supra note 17, at 99. 
in a proper understanding of the appetites and aversions of human beings. The process theorists claimed that theirs were immanent in the institutional structure and the constitutional documents. But if that is the case, both projects must surely be limited to pure description; they have no power to say that any existing practice is wrong, because the theory is supposed to come from an analysis of existing practice.

The next move is to identify some practices as aberrant: mistakes, perversions, and deviations from the true path. But that supposes a meta-principle that identifies the real path and where does the metaprinciple come from? Yo ho and we're off into the familiar infinite regress. The purposive project fails, as did the essentialist project that went before it. It may seem as though I am saying that the mistakes are really the same-transcendental essences, transcendental purposes, ça ne faire rien-it is a difference that is no difference. But I must admit that it seems like an advance to me, a sentiment that, at first, caused me all kinds of historicist shame.

There are a number of explanations for thinking that Hobbes's ideas (and to a lesser extent, those of the process theorists) are doing something more worthwhile than those of the essentialists against whom they reacted. It might be simply that the brilliance of Hobbes's thought becomes more important than its soundness. Aubrey thought that was the case: "But one may say of him, as one sayes of Jos. Scaliger, that where he erres, he erres so ingeniosely, that one had rather erre with him then hitt the marke with Clavius." "151 But I think there is a better reason.

Hobbes opens up the connection between the language of power and the power of language. $\mathrm{He}$, more than any of his contemporaries, seems to have been aware of the power that one could exercise if one could grasp and define an existing source of legitimacy, or even create a new source. Whether it was natural law, provincial law, time-honored custom, or the interpretive abilities of the subordinate judge, Hobbes was determined to show that it must all be linked back to the sovereign. And in the course of doing this, he followed the path wherever it led. To understand society, you had to understand motion, and relationships, and universals, and essences, and sentiments, and optics, and who knows what else. So Hobbes wrote about them. He realized that most of the questions with which he was dealing resolved themselves into questions about epistemology-what is it to Know, to be Right? So he wrote about epistemology, and politics, and legal theory, and biblical interpretation. If we are only now beginning to see the connections be-

181 J. AUBREY, supra note 19, at 151. 
[Vol. 135:383

tween a theory of knowledge, a theory of interpretation, a theory of judicial review, and the legitimacy of the state, we cannot blame Hobbes. He had always said these things were connected, and he offered us a picture of how they might be connected, which, even though we may think it is wrong, has never been surpassed in its coherence, its power, and its depth.

Hobbes is like the magician who tells you where the trick is and still dares you to spot it. He shows the emptiness of all theories that relied on the defining of essences and still rests his legal theory on a definition of the necessary attributes of law. It is only when one traces that theory from its nominalist beginnings, through its science of motion, its analysis of human motivations, and its recomposed state that one realizes how much more it is than a positivist definition of law. It is a tool kit of political arguments, it is an anti-professional attack on philosophers and lawyers, it is a pragmatist theory of meaning, it is a justification for the authoritarian state, it is Wittgenstein without the Tractatus, ${ }^{162}$ and it is a demonstration of the connection between politics, law, and language.

${ }^{182}$ L. Wittgenstein, Tractatus Logico-Philosophicus (1922). 